\title{
Assessment of allelopathic potential of Couroupita guianensis Aubl.
}

\author{
Md Sirajul Islam Khan* and Hisashi Kato-Noguchi
}

\author{
Laboratory of Plant Biochemistry, Department of Applied Biological Science, Faculty of Agriculture, \\ Kagawa University, Miki, Kagawa, 761-0795, Japan
}

\author{
*Corresponding author: sirajsau@gmail.com
}

\begin{abstract}
Couroupita guianensis Aubl. has been traditionally used for medicinal as well as ornamental purposes, but the allelopathic potential of this species has not yet been reported. Hence, the aim of this study is to explore the allelopathic activity of $C$. guianensis leaves. We examined the effect of aqueous methanol extracts of the leaves of this species at five different concentrations $(1,3,10,30$, and $100 \mathrm{mg}$ dry weight (DW) equivalent extract $\mathrm{mL}^{-1}$ ) on the germination of lettuce (Lactuca sativa L.) and barnyard grass (Echinochloa crus-galli (L.) Beauv.), and on the growth of cress (Lepidium sativum L.), lettuce, alfalfa (Medicago sativa L.), barnyard grass, timothy (Phleum pretense L.), and Italian ryegrass (Lolium multiflorum Lam.) seedlings. The germination of lettuce and barnyard grass, as well as the growth of all test plants, was inhibited by leaf extracts of $C$. guianensis at concentrations $\geq 1 \mathrm{mg}$ DW equivalent extract $\mathrm{mL}^{-1}$. The extract obtained from $100 \mathrm{mg}$ C. guianensis leaves completely inhibited germination of lettuce or significantly delayed germination of barnyard grass. The hypocotyl/coleoptile and root growth of all test plants were inhibited by the leaf extracts to less than $10 \%$ of control hypocotyl/coleoptile and root growth at the concentration of $100 \mathrm{mg} \mathrm{DW}$ equivalent extract $\mathrm{mL}^{-1}$, except for the hypocotyl/coleoptile growth of alfalfa and barnyard grass. The ranges of $I_{50}$ values of hypocotyl/coleoptile and root growth of all test plants were 1.22-10.24 and 0.76-3.97 mg DW equivalent extract $\mathrm{mL}^{-1}$, respectively. The inhibitory activities increased with increasing extract concentrations. The present results suggest that $C$. guianensis may have allelopathic potential and thus possesses allelopathic substances. Therefore, the leaves of this species could potentially be used as mulch and/or soil additive to control weeds in sustainable crop production.
\end{abstract}

Keywords: Allelopathic substances; bioassay; cannon-ball tree; inhibitory activity; sustainable weed management. Abbreviations: DW_dry weight; $I_{50 \_}$concentration required for 50\% inhibition; CRD_completely randomized design.

\section{Introduction}

Couroupita guianensis Aubl. (cannon-ball tree), originating in tropical north-eastern South America, especially the Amazon rainforest, belongs to the Lecythidaceae family and is widely planted as a botanical curiosity in tropical and subtropical regions of the world (Lim, 2012; Al-Dhabi et al., 2012). It is one of the most spectacular plants because of its showy scanty flowers and peculiar spherical woody fruit (Mori et al., 2007). Couroupita guianensis has been frequently found in wet areas of lowlands and river banks subject to periodic flooding, and it grows well in moist soils but thrives under dry conditions because of its hygrophyte and heliophyte nature (Brown, 2006; Lim, 2012). It is a fastgrowing deciduous tree, and almost all of the parts of this species, namely leaves, fruit, flowers, stems, roots, and seeds, have been reported to contain chemical constituents, such as triterpenes, phenolics, couroupitine, indirubin, isatin, and oils (Begum et al., 2009; Gousia et al., 2013).

Global population is increasing rapidly day by day, but the production of crops is not increasing at the same rate. To cope with this situation, researchers are now facing unprecedented challenges to increase production to ensure the food security of this burgeoning population. Oerke (2006) and Jabran et al. (2015) reported that worldwide yield losses of major agricultural crops caused by weeds were about $34 \%$, which is higher than the losses caused by other pests. In this regard, farmers rely on synthetic herbicides to control weeds in their crop fields because of easy accessibility and a more rapid return. The control of weeds using such agrochemicals results in maximum crop yields, but there are negative environmental and human health issues caused by indiscriminate use. To overcome these harmful effects, there is an alternative, sustainable option of using allelopathic plants to minimize dependency on synthetic herbicides in an agro-ecosystem. Allelopathic plants are those plants that release allelopathic substances into the surrounding environment through a number of physico-chemical actions. These allelopathic substances may interfere directly or indirectly with the growth and development of nearby plant species (Fitter, 2003; Weir et al., 2004). This method of controlling weeds is considered environmentally friendly compared with commercial herbicides (Hoagland and Cutler, 2000; Duke et al., 2010). Plants produce a diverse number of secondary metabolites, and some of them have been treated as allelopathic substances because of their potential phytotoxicity (Field et al., 2006; Kato-Noguchi et al., 2014). Therefore, many researchers have been interested in isolating and identifying those allelopathic substances from different allelopathic plants because of their weed suppression ability, and these substances have been used for sustainable weed management systems (Islam et al., 2014; Miranda et al., 2015). Moreover, tree species with allelopathic potential may promote the stability of agro-forestry systems, especially for weed control (Macias et al., 2010; Chu et al., 2014). 
Table 1. $I_{50}$ values (mg DW equivalent extract $\mathrm{mL}^{-1}$ ) of hypocotyl/coleoptile and root growth of six test plants when treated with aqueous methanol extracts of $C$. guianensis leaves.

\begin{tabular}{llll}
\hline \multirow{2}{*}{ Test plant } & \multirow{2}{*}{ Type of test plant } & \multicolumn{2}{l}{$I_{50}\left(\mathrm{mg} \mathrm{DW}\right.$ equivalent extract $\left.\mathrm{mL}^{-1}\right)$} \\
\cline { 3 - 4 } & & Hypocotyl/coleoptile & Root \\
\hline Cress & \multirow{2}{*}{ Dicotyledonous } & 2.3 & 1.69 \\
Lettuce & 2.24 & 1.75 \\
Alfalfa & 2.27 & 0.88 \\
\hline Barnyard grass & \multirow{2}{*}{ Monocotyledonous } & 10.01 & 2.27 \\
Timothy & & 3.58 & 0.76 \\
Italian ryegrass & & 1.22 & 3.97 \\
\hline Note: $I_{50}$ values were measured based on a curve-fitting logistic equation of dose response after bioassays.
\end{tabular}

Note: $I_{50}$ values were measured based on a curve-fitting logistic equation of dose response after bioassays.

The leaves of $C$. guianensis are of particular interest from a pharmacological point of view. Leaf extracts of $C$. guianensis exhibit potential pharmacological effects such as antiinflammatory (Pinheiro et al., 2013), antimicrobial (Khan et al., 2003), antifungal (Sathe et al., 2013), antinociceptive (Pinheiro et al., 2010), anti-ulcer, anti-cancer, anti-arthritic (Elumalai et al., 2012), antidiarrheal (Elumalai et al., 2013), anti-diabetic (Swapnalatha and Devi, 2014), and antioxidant (Begum et al., 2009). In addition, the leaf extracts of this species possess cytotoxic activity against breast cancer cells (Devaraj et al., 2013), a pesticidal effect on the larval stage of insects (Baskar et al., 2010), and an ovicidal activity against leaf worm moth (Baskar et al., 2014). It was observed that the vegetation under a $C$. guianensis canopy is scant (Fig.1). However, so far no literature was found regarding the bareness of plant growth under or near $C$. guianensis tree. One possible reason for the inhibition or suppression could be the allelopathic potential of this species. Although $C$. guianensis has significant traditional medicinal value, it has not yet been explored with respect to allelopathic activities. The present study compiles updated information regarding the allelopathic potential of $C$. guianensis to develop a possible alternative natural weed management strategy. Therefore, the current research was conducted to check the allelopathic potential of aqueous methanol extracts of $C$. guianensis leaves against six test plants, including three weeds, under laboratory conditions.

\section{Results}

Effects of the leaf extracts of $\mathrm{C}$. guianensis on the germination of lettuce and barnyard grass seeds

Figure 2 indicates that the germination of both lettuce and barnyard grass was inhibited at extract concentrations $\geq 1 \mathrm{mg}$ DW equivalent extract $\mathrm{mL}^{-1}$. At the concentration of $100 \mathrm{mg}$ DW equivalent extract $\mathrm{mL}^{-1}$, no seed germination was found in lettuce, and 30\% germination was observed in barnyard grass on $96 \mathrm{~h}$ incubation. In contrast, $1 \mathrm{mg} \mathrm{mL}^{-1}$ of leaf extract showed the germination of lettuce and barnyard grass to 70 and $90 \%$, respectively, on $96 \mathrm{~h}$ incubation. In addition, significant delayed of germination was found in both test plants at the concentration of $30 \mathrm{mg}$ DW equivalent extract $\mathrm{mL}^{-1}$. It was found that lettuce exhibited more sensitivity to the extracts than barnyard grass. The inhibition of germination of both seeds was related to the extract concentrations, which indicates that the inhibition of germination increased with increasing extract concentrations.

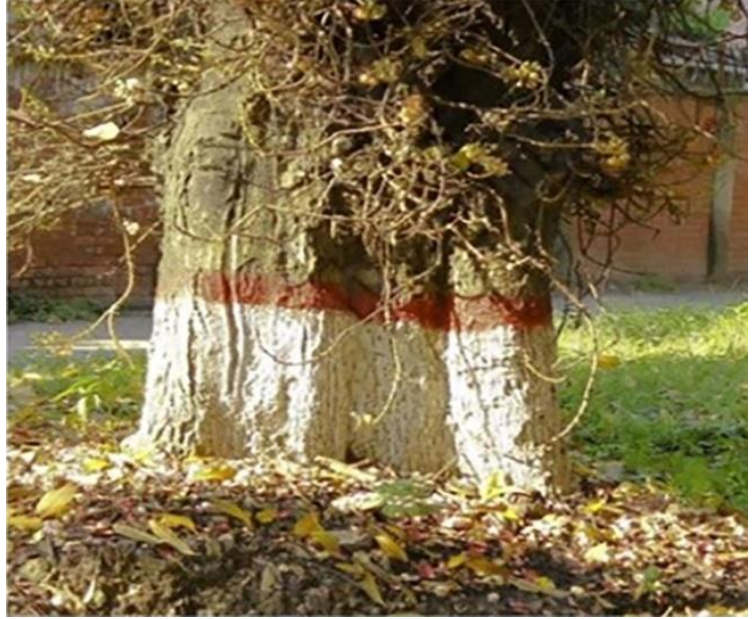

Fig 1. The suppression zone of $C$. guianensis that inhibits the growth and development of weeds and some plant species under or near its tree canopy in a natural ecosystem.

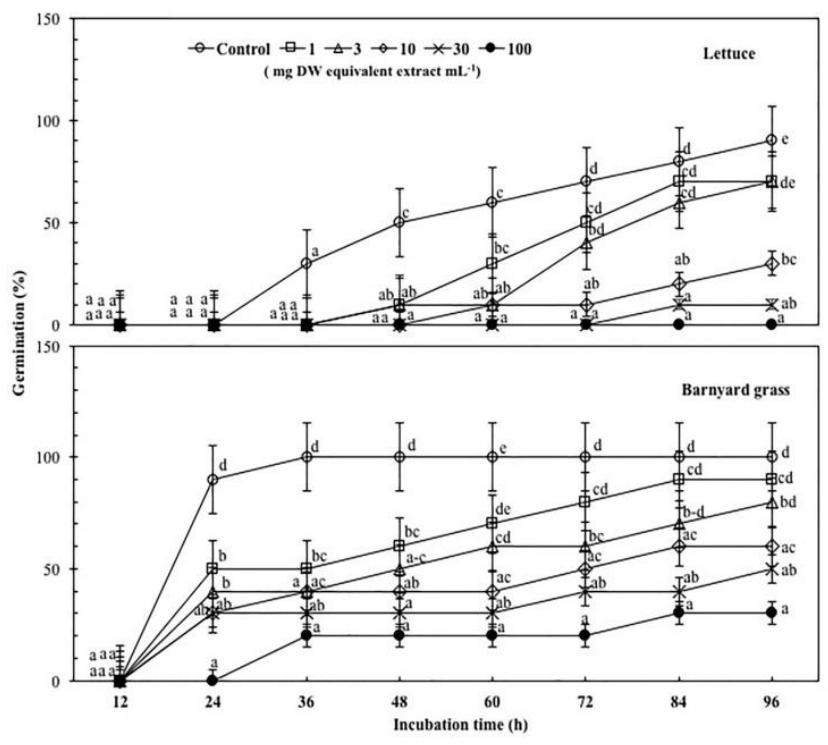

Fig 2. Effect of aqueous methanol extracts of $C$. guianensis leaves on the germination of lettuce and barnyard grass at 12 $\mathrm{h}$ intervals for $96 \mathrm{~h}$ of incubation in darkness at $25^{\circ} \mathrm{C}$. The concentrations of tested samples were $1,3,10,30$, and 100 mg DW equivalent extract $\mathrm{mL}^{-1}$. Means $\pm \mathrm{SE}$ from 3 independent experiments with 3 replicate Petri dishes for each treatment $(n=90)$. Different letters within particular incubation time are significantly different at $\mathrm{P} \leq 0.05$. 


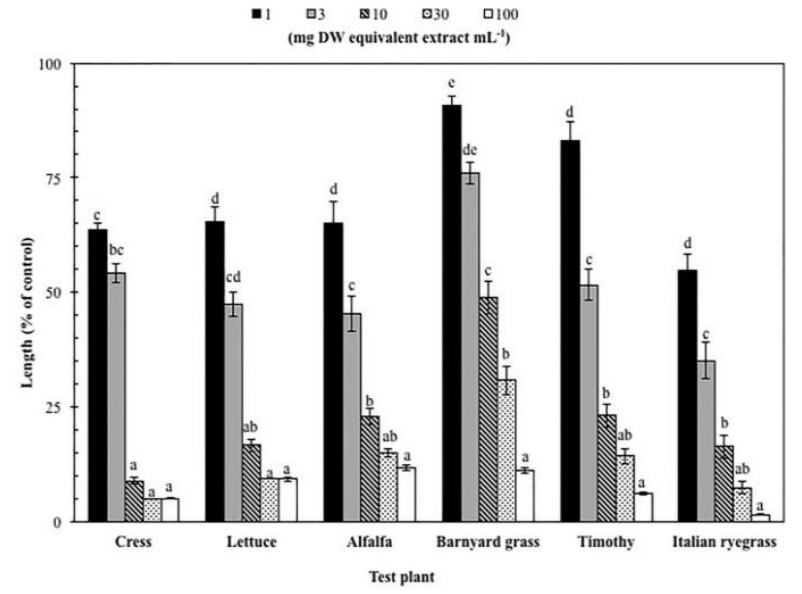

Fig 3. Effect of aqueous methanol extracts of $C$. guianensis leaves on the hypocotyl/coleoptile growth of three plants (cress, lettuce, and alfalfa) and three weed species (barnyard grass, timothy, and Italian ryegrass). The concentrations of tested samples were $1,3,10,30$, and $100 \mathrm{mg}$ DW equivalent extract $\mathrm{mL}^{-1}$. Hypocotyl/coleoptile length was checked after $48 \mathrm{~h}$ of incubation in darkness at $25^{\circ} \mathrm{C}$. Means \pm SE from 3 independent experiments with 3 replicate Petri dishes for each treatment $(n=90)$. Means above each bar followed by different letters are significantly different at $\mathrm{P} \leq 0.05$.

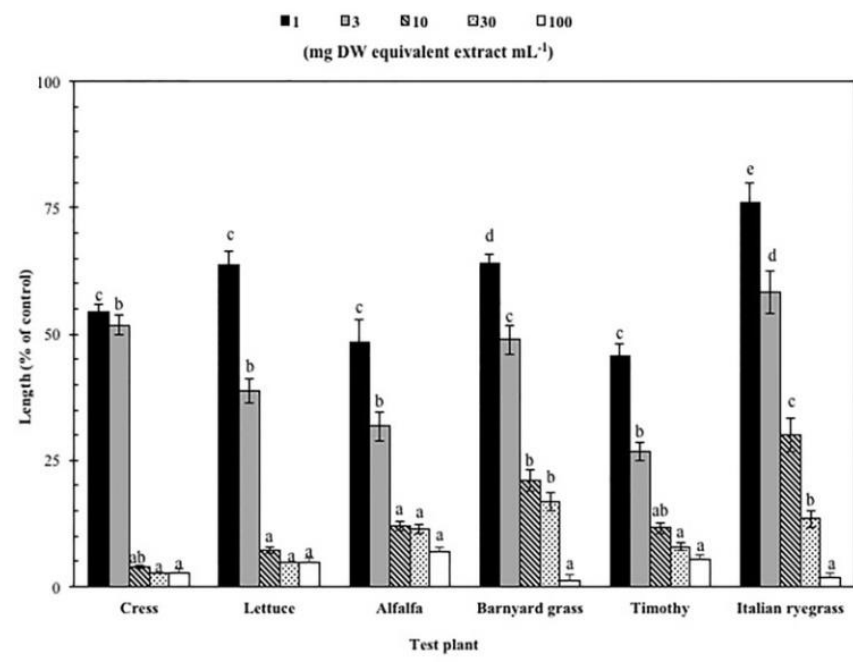

Fig 4. Effect of aqueous methanol extracts of C. guianensis leaves on the root growth of three plants (cress, lettuce, and alfalfa) and three weed species (barnyard grass, timothy, and Italian ryegrass). The concentrations of tested samples were $1,3,10,30$, and $100 \mathrm{mg} \mathrm{DW}$ equivalent extract $\mathrm{mL}^{-1}$. Hypocotyl/coleoptile length was checked after $48 \mathrm{~h}$ of incubation in darkness at $25^{\circ} \mathrm{C}$. Means \pm SE from 3 independent experiments with 3 replicate Petri dishes for each treatment $(n=90)$. Means above each bar followed by different letters are significantly different at $\mathrm{P} \leq 0.05$.

\section{Effects of the leaf extracts of $C$. guianensis on the hypocotyl/coleoptile and root growth of the six test plants}

The hypocotyl/coleoptile and root growth of the six test plants was significantly inhibited by the leaf extracts at concentrations $\geq 3 \mathrm{mg}$ DW equivalent extract $\mathrm{mL}^{-1}$ (Figs. 3 and 4), and the inhibitory activities increased with increasing extract concentrations. The extract obtained from $100 \mathrm{mg} C$. guianensis leaves inhibited hypocotyl/coleoptile growth of cress, lettuce, timothy, and Italian ryegrass to less than $10 \%$ of control hypocotyl/coleoptile growth, and inhibited hypocotyl/coleoptile growth of alfalfa and barnyard grass to 12 and $11 \%$ of control hypocotyl/coleoptile growth, respectively. In contrast, $1 \mathrm{mg} \mathrm{mL} \mathrm{m}^{-1}$ of extract inhibited hypocotyl/coleoptile growth of cress, lettuce, alfalfa, barnyard grass, timothy and Italian ryegrass to $63.6,65.4$, $65.2,90.6,83$, and $54.9 \%$ of control hypocotyl/coleoptile growth, respectively. At concentrations of 10 and $30 \mathrm{mg}$ DW equivalent extract $\mathrm{mL}^{-1}$, leaf extracts inhibited hypocotyl/coleoptile growth of cress, lettuce, alfalfa, timothy, and Italian ryegrass to less than $25 \%$ of control hypocotyl/coleoptile growth, and inhibited coleoptile growth of barnyard grass to 49 and $31 \%$ of control coleoptile growth, respectively (Fig. 3).

The extract obtained from $100 \mathrm{mg} C$. guianensis leaves inhibited root growth of all test plants to less than $10 \%$ of control root growth. In addition, $C$. guianensis leaves completely or almost completely inhibited root growth of barnyard grass and Italian ryegrass, respectively at the concentration of $100 \mathrm{mg}$ DW equivalent extract $\mathrm{mL}^{-1}$. In contrast, $1 \mathrm{mg} \mathrm{mL}^{-1}$ extract inhibited root growth of cress, lettuce, alfalfa, barnyard grass, timothy and Italian ryegrass to $54.3,63.6,48.5,63.9,45.6$, and $75.9 \%$ of control root growth, respectively (Fig. 4). At concentrations of 10 and 30 mg DW equivalent extract $\mathrm{mL}^{-1}$, leaf extracts inhibited root growth of all the test plants to less than $35 \%$ of control root growth (Fig. 4). The leaf extracts inhibited total mean hypocotyl/coleoptile growth of cress, lettuce, alfalfa, barnyard grass, timothy, and Italian ryegrass to $27.4,29.7$, $32.03,51.5,35.7$, and $23.1 \%$ of control hypocotyl/coleoptile growth, respectively, and inhibited total mean root growth of cress, lettuce, alfalfa, barnyard grass, timothy, and Italian ryegrass to $23.0,23.8,22.1,30.4,19.4$, and $35.9 \%$ of control root growth, respectively (Fig. 5).

The $I_{50}$ values show that $1.22-10.24 \mathrm{mg}$ leaf extract of $C$. guianensis inhibited hypocotyl/coleoptile growth by $50 \%$. These results indicate that Italian ryegrass was the most sensitive to the leaf extract, whereas barnyard grass was the least sensitive with respect to $I_{50}$ values. On the other hand, 0.76-3.97 mg leaf extract inhibited root growth by $50 \%$. Considering the $I_{50}$ values of root growth of all the test plants, timothy was the most sensitive to the leaf extract, whereas Italian ryegrass was the least sensitive test plant (Table 1).

\section{Discussion}

We determined the inhibitory activities of leaf extracts obtained from $C$. guianensis on the germination of lettuce and barnyard grass, as well as on the growth of cress, lettuce, alfalfa, barnyard grass, timothy and Italian ryegrass seedlings. The results showed that the aqueous methanol extracts of $C$. guianensis leaves significantly inhibited germination and growth of all the test plants at concentrations greater than $1 \mathrm{mg} \mathrm{DW}$ equivalent extract $\mathrm{mL}^{-1}$ (Figs. 2, 3, and 4). These inhibitory responses correlated to extract concentrations (Fig. 6), which implies that this species has allelopathic substances. The concentration-dependent inhibitory effects of allelopathic plant extracts were also observed by Aslani et al. (2014), Abu-Rohman and Ammari (2015), Duke (2015), and Miranda et al. (2015). Furthermore, Liu et al. (2003) also found that some allelopathic substances inhibit growth at higher concentrations but stimulate growth at lower concentrations.

In the present study, the leaf extracts of $C$. guianensis completely inhibited the germination of lettuce and significantly delayed germination of barnyard grass. A similar pattern of inhibition of germination was reported by 


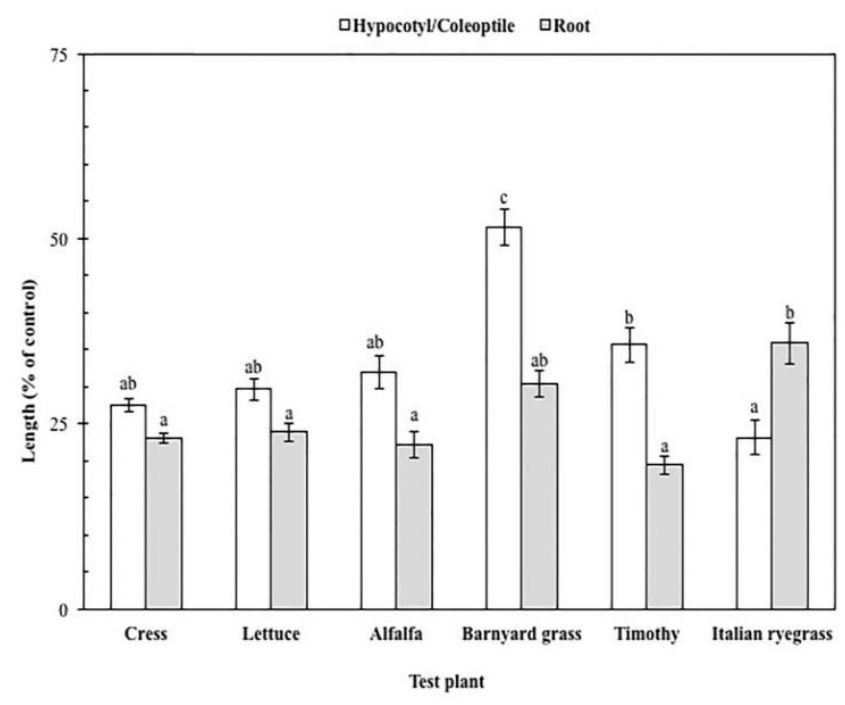

Fig 5. Effect of extract obtained from C. guianensis leaves on overall mean growth of hypocotyl/coleoptile and root of all test plants. Means \pm SE from 3 independent experiments with 3 replicate Petri dishes for each treatment $(n=90)$. Means \pm SE from 3 independent experiments with 3 replicate Petri dishes for each treatment $(n=90)$. Means above each bar followed by different letters are significantly different at $\mathrm{P} \leq 0.05$.

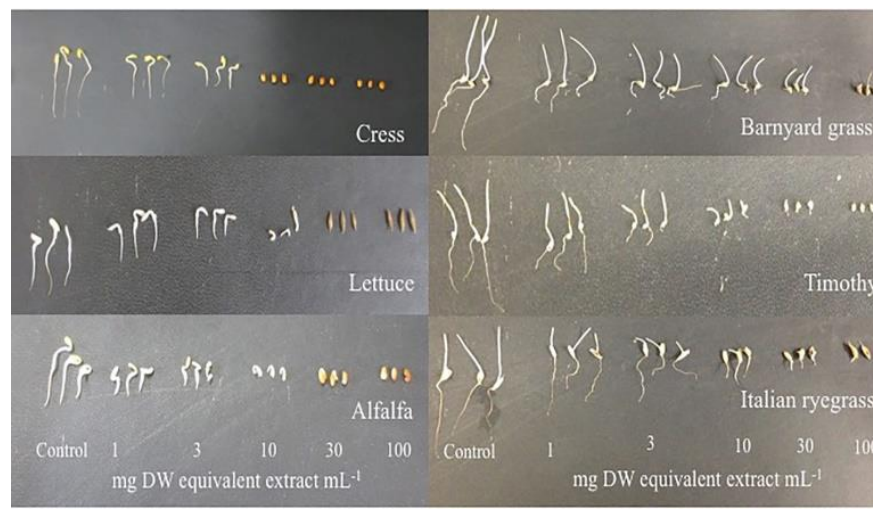

Fig 6. Effect of aqueous methanol extracts of $C$. guianensis leaves on the seedling growth of cress, lettuce, alfalfa, barnyard grass, timothy, and Italian ryegrass at concentrations of tested samples corresponding to the extract obtained from 1, 3, 10, 30, and $100 \mathrm{mg}$ DW equivalent extract $\mathrm{mL}^{-1}$.

Escudero et al. (2000). The reasons for the inhibitory effects of germination caused by allelopathic substances could be i) disruption and impairment of mitochondrial respiration, ii) breakdown of the activities of metabolic enzymes (Weir et al., 2004), iii) breakage of cells leading to cell death (Lin et al., 2000), and iv) correlation with increased cell membrane degradation (Bogatek et al., 2006).

Based on the $I_{50}$ values of all the test plants, we found more effective inhibition of hypocotyl/coleoptile and root growth of the dicotyledonous test plants than that of monocotyledonous. The leaf extracts of C. guianensis showed different inhibitory activities on different test plants, which indicates that the variation in selectivity of allelopathic substances was specific against target plants. The possibility of such unequal susceptibility to extracts may be due to the involvement of biochemicals with their different inherent responses. Test plant specific inhibitory responses were reported by Khanh et al. (2006), where Passiflora edulis aqueous extracts strongly suppressed the growth of lettuce and radish, whereas, the growth of barnyard grass was less affected. In addition, different sensitivity to allelopathic substances on various test plants has also been reported in another study (Hussain and Reigosa, 2011). Considering the hypocotyl/coleoptile and root growth of all the test plants, root growth was more sensitive to the extracts than hypocotyl/coleoptile growth. The causes of high sensitivity in the roots to allelopathic substances may be due to i) the involvement of root growth in both cell expansion and cell proliferation (Nishida et al., 2005), ii) higher permeability of allelopathic substances in root surfaces than the hypocotyl/coleoptile (Yoshimura et al., 2011), and iii) direct proximity between the roots and the extracts (Qasem, 1995).

\section{Materials and Methods}

\section{Plant materials}

Leaves of $C$. guianensis were collected from Sher-e-Bangla Agricultural University campus, Dhaka, Bangladesh $\left(23^{\circ} 77^{\prime}\right.$ $\mathrm{N}$ latitude and $90^{\circ} 33^{\prime} \mathrm{E}$ longitude) during January and February 2013. This species was taxonomically identified by the researchers of the National Herbarium, Ministry of Environment and Forest, Dhaka, Bangladesh, where a voucher specimen was deposited for this sample (accession number is DACB-32,062). After collection, leaves were washed, and dried in the sun; the dried leaves were then ground to powder form and kept in a refrigerator at $4{ }^{\circ} \mathrm{C}$ until extraction.

\section{Test species}

Seeds of uniform shape and size of the three dicotyledonous plants (cress, lettuce, and alfalfa) and three monocotyledonous weeds (barnyard grass, timothy, and Italian ryegrass) were chosen in this experiment. Cress and lettuce seeds were purchased from Nakahara Seed Product Co. Ltd (Fukuoka, Japan) and Tohoku Seed Co. Ltd (Utsunomiya, Japan), respectively, whilst alfalfa, Italian ryegrass, and timothy seeds were purchased from Takii Seed Co. Ltd. (Kyoto, Japan). Barnyard grass seeds were obtained from a local farmer's field (Miki-cho, Kagawa, Japan). Cress, lettuce, alfalfa, and timothy were chosen for their known growth patterns (Islam et al., 2013), whereas, Italian ryegrass and barnyard grass were selected because they are regarded globally as deleterious weeds (Salam and Kato-Noguchi, 2009; Khan et al., 2013; Thi et al., 2014).

\section{Extraction of leaf powder of C. guianensis}

Leaf powder (30 g) of C. guianensis was extracted with 250 $\mathrm{mL}$ of $70 \%(\mathrm{v} / \mathrm{v})$ aqueous methanol for $48 \mathrm{~h}$. The extract was then filtered through one layer of filter paper (No. 2; Toyo, Tokyo, Japan) on a Buchner funnel by using a vacuum pump. The residue was re-extracted with an equal volume of methanol for $24 \mathrm{~h}$ and filtered. The two filtrates were then combined and evaporated to dryness using a rotary evaporator at $40{ }^{\circ} \mathrm{C}$.

\section{Germination bioassay}

An aliquot of the $C$. guianensis leaf extract (final assay concentrations were $1,3,10,30$, and $100 \mathrm{mg}$ DW equivalent extract $\mathrm{mL}^{-1}$ ) was evaporated to dryness, dissolved in the required volume of methanol, and added to a sheet of filter 
paper in a $2.8 \mathrm{~cm}$ Petri dish. After evaporating methanol in a laminar flow, $0.6 \mathrm{~mL}$ of an aqueous solution of $0.05 \%(\mathrm{v} / \mathrm{v})$ of Tween 20 (polyoxyethylene sorbitan monolaurate, Nacalai Tesque, Inc., Kyoto, Japan) was added to the filter paper. Ten seeds of lettuce and barnyard grass (after soaking in distilled water to imbibe the seeds) were arranged on filter paper in the Petri dishes. The control treatment was the same as described above with the exception of filter paper moistened with Tween 20 without leaf extracts. After that, the Petri dishes were arranged in a plastic tray and covered with polyethylene and aluminum foil. The Petri dishes were then incubated in a dark chamber at $25^{\circ} \mathrm{C}$. Seeds that showed the emergence of a $1 \mathrm{~mm}$ radicle by rupturing the seed coat were considered to be germinated as described in our previous study (Islam et al., 2013). Germination of seeds was recorded at $12 \mathrm{~h}$ intervals for $96 \mathrm{~h}$ until the germinated seeds were constant. The percentage of germination was calculated using the following formula:

Germination $(\%)=\left(\mathrm{G}_{\mathrm{A}} / \mathrm{G}_{0}\right) \times 100$

$\mathrm{G}_{\mathrm{A}}=$ average number of germinated seeds in the treatment at each time of measurement

$\mathrm{G}_{0}=$ average number of germinated seeds in the control at the same time of measurement

\section{Growth bioassay}

The plant extracts, and their placing in Petri dishes were prepared as described in the germination bioassay section. Ten seeds of cress, lettuce, alfalfa, and 10 pre-germinated seeds of timothy (germinated in darkness at $25{ }^{\circ} \mathrm{C}$ for $84-96$ h), Italian ryegrass (germinated in darkness at $25^{\circ} \mathrm{C}$ for $36-$ $48 \mathrm{~h}$ ) and barnyard grass (germinated in darkness at $25^{\circ} \mathrm{C}$ for 48-60 h) were arranged on filter paper in Petri dishes containing $0.6 \mathrm{~mL}$ of $0.05 \%(\mathrm{v} / \mathrm{v})$ Tween 20. All the Petri dishes were kept in a growth chamber in a dark condition at $25{ }^{\circ} \mathrm{C}$. Control seeds were placed on filter paper moistened with Tween 20 without leaf extracts. The hypocotyl /coleoptile and root lengths of the seedlings were measured after $48 \mathrm{~h}$ incubation. The growth bioassay experiment was conducted as per Khan et al. (2013) with slight modifications.

\section{Statistical analysis}

All experiments were conducted in a completely randomized design (CRD) with 3 replicate Petri dishes and the experiment was repeated 3 times $(n=90)$. The experimental data were analysed using predictive analytics software SPSS 16.0 (SPSS Inc., Chicago, Illinois, USA). Tukey's HSD multiple comparison tests were used to analyse the significant differences between control and treatments at $\mathrm{P} \leq 0.05$. The concentration required for $50 \%$ growth inhibition (defined as $I_{50}$ ) of the test plants in the assays was calculated from the regression equation of the concentration response curves, using Graph Pad Prism 6.0 (Graph Pad Software, Inc., La Jolla, California, USA).

\section{Conclusions}

The aqueous methanol extracts of C. guianensis leaves had inhibitory activity on the germination and growth of six test plants, including three weeds, suggest that this species has allelopathic potential and may possess allelopathic substances. Therefore, this species could be a candidate for isolation and identification of those active substances to serve as a supplement for synthetic herbicides, which may favorably use for incorporating in agricultural systems for weed management in sustainable manner. However, more research is required to check the allelopathic potential of this species under greenhouse and different field conditions.

\section{Acknowledgements}

The authors thank to Japanese Ministry of Education, Culture, Sports, Science and Technology (MEXT) for providing financial support to carry out this research. We also thankfully acknowledged to Dr. Dennis Murphy, UGAS Ehime University, Japan for editing the English language of the whole manuscript.

\section{References}

Abu-Rohman S, Ammari T (2015) Allelopathic effect of Arundo donax, a mediterranean invasive grass. Plant Omics. 8:287-291.

Al-Dhabi NA, Balachandran C, Raj MK, Duraipandiyan V, Muthukumar C, Ignacimuthu S, Khan IA, Rajput VS (2012) Antimicrobial, antimycobacterial and antibiofilm properties of Couroupita guianensis Aubl. fruit extract. BMC Complem Altern M. 12:1-8.

Aslani F, Juraimi AS, Ahmad-Hamdani AS, Omar D, Alam MA, Hashemi FSG, Hakim MA, Uddin MK (2014) Allelopathic effect of methanol extracts from Tinospora tuberculata on selected crops and rice weeds. Acta Agr Scand B-S P. 64:165-177.

Baskar K, Maheswaran R, Kingsley S, Ignacimuthu S (2010) Bioefficacy of Couroupita guianensis (Aubl) against Helicoverpa armigera (Hub.) (Lepidoptera: Noctuidae) larvae. Span J Agric Res. 8:135-141.

Baskar K, Muthu C, Ignacimuthu S (2014) Ovicidal activity of Couroupita guianensis (Aubl.) against Spodoptera litura (Fab.) Psyche. 2014:1-5.

Begum R, Rahman MS, Chowdhury AMS, Hasan CM, Rashid MA (2009) Secondary metabolites (triterpenes) from Couroupita guianensis. Orient Pharm Exp Med. 9:200-205.

Bogatek R, Gniazdowska A, Zakrzewska W, Oracz K, Gawronski SW (2006) Allelopathic effects of sunflower extracts on mustard seed germination and seedling growth. Biol Plantarum. 50:156-158.

Brown SH (2006) Couroupita guianensis. University of Florida, IFAS Extension, Gainesville, Florida A\&M, USA.

Chu C, Mortimer PE, Wang H, Wang Y, Liu X, Yu S (2014) Allelopathic effects of eucalyptus on native and introduced tree species. Forest Ecol Manag. 323:79-84.

Devaraj P, Kumari P, Aarti C, Renganathan A (2013) Synthesis and characterization of silver nanoparticles using cannonball leaves and their cytotoxic activity against MCF7 cell line. J Nanotechnology. 2013:1-5.

Duke SO, Cantrell CL, Meepagala KM, Wedge D, Tabanca EN, Schrader KK (2010) Natural toxins for use in pest management. Toxins. 2:1943-1962.

Duke SO (2015) Proving allelopathy in crop-weed interactions. Weed Sci. 63:121-132.

Elumalai A, Naresh V, Eswaraiah MC, Narendar P, Kumar R (2012) Evaluation of antiulcer activity of Couroupita guianensis Aubl. leaves. Asian J Pharm Tech. 2:64-66.

Elumalai A, Eswaraiah MC, Koppula NK, Kumar R, Meruva A, Vidhyulatha C (2013) Antidiarrhoeal activity of Couroupita guianensis leaves on castor oil induced diarrhoea in albino rats. Int J Pharm Res. 3:42-44.

Escudero A, Albert MJ, Pita JM, Garcia FP (2000) Inhibitory effects of Artemisia herba-alba on the germination of the gypsophyte Helianthemum squamatum. Plant Ecol. 148:71-80. 
Field B, Jordan F, Osbourn A (2006) First encounters deployment of defense-related natural products by plants. New Phytol. 172:193-207.

Fitter A (2003) Making allelopathy respectable. Science. 301:1337-1338.

Gousia SK, Kumar KA, Kumar TV, Latha JNL (2013) Biological activities and medicinal properties of Couroupita guianensis. Int J Pharm Pharm Sci. 3:140-143.

Hoagland RE, Cutler SJ (2000) Plant and microbial compounds as herbicides. In: Narwal SS, Hoagland RE, Dilday RH, Reigosa MJ (eds), Allelopathy in Ecological Agriculture and Forestry, Springer, Kluwer Academic Publishers, Dordrecht, The Netherlands, pp.73-99.

Hussain MI, Reigosa MJ (2011) Allelochemical stress inhibits growth, leaf water relations, PSII photochemistry, non-photochemical fluorescence quenching, and heat energy dissipation in three $\mathrm{C}_{3}$ perennial species. J Exp Bot. 62:4533-4545.

Islam AKMM, Khan MSI, Kato-Noguchi H (2013) Allelopathic activity of Litchi chinensis Sonn. Acta Agr Scand B-S P. 63:669-675.

Islam AKMM, Ohno O, Suenaga K, Kato-Noguchi H (2014). Two novel phytotoxic substances from Leucas aspera. J Plant Physiol. 171:877-883

Jabran K, Mahajan G, Sardana V, Chauhan BS (2015) Allelopathy for weed control in agricultural systems. Crop Prot. 72: 57-65.

Kato-Noguchi H, Salam MA, Ohno O, Suenaga K (2014) Nimbolide B and nimbic acid B, phytotoxic substances in neem leaves with allelopathic activity. Molecules. 19:6929-6940.

Khan MR, Kihara M, Omoloso AD (2003) Antibiotic activity of Couroupita guianensis. J Herbs Spices Med Plants. 10:95-108.

Khan MSI, Islam AKMM, Kato-Noguchi H (2013) Evaluation of allelopathic activity of three mango (Mangifera indica) cultivars. Asian J Plant Sci. 12:252261.

Khanh TD, Chung IM, Tawata S, Xuan TD (2006) Weed suppression by Passiflora edulis and its potential allelochemicals. Weed Res. 46:296-303.

Lim TK (2012) Couroupita guianensis. In: Lim TK (ed), Edible Medicinal and Non-Medicinal Plants, Springer, Dordrecht, The Netherlands, pp.133-137.

Lin WX, Kim KU, Shin DH (2000) Rice allelopathic potential and its modes of action on barnyard grass (Echinochloa crus-galli). Allelopathy J. 7:215-224.

Liu DL, An M, Johnson IR, Lovett JV (2003) Mathematical modeling of allelopathy. III. A model for curve-fitting allelochemical dose responses. Nonlinearity Biol Toxicol Med. 1:37-50.

Macias FA, Lacret R, Varela RM, Nogueiras C, Molinillo JMG (2010) Isolation and phytotoxicity of terpenes from Tectona grandis. J Chem Ecol. 36:396-404.

Miranda MAM, Varela RM, Torres A, Molinillo JMG, Gualtieri SCJ, Macias FA (2015) Phytotoxins from Tithonia diversifolia. J Nat Prod. 78:1083-1092.
Mori SA, Tsou CA, Wu CC, Cronholm B, Anderberg AA (2007) Evolution of Lecythidaceae with an emphasis on the circumscription of neotropical genera: information from combined Ndhf and Trnl-F sequence data. Am J Bot. 94:289-301.

Nishida N, Tamotsu S, Nagata N, Saito C, Saka A (2005) Allelopathic effects of volatile monoterpenoids produced by Salvia leucophylla: inhibition of cell proliferation and DNA synthesis in the root apical meristem of Brassica campestris seedlings. J Chem Ecol. 31:1187-1203.

Oerke EC (2006) Crop losses to pests. J Agric Sci. 144:3143.

Pinheiro MMG, Bessa SO, Fingolo CE, Kuster RM, Matheus ME, Menezes FS, Fernandes PD (2010). Antinociceptive activity of fractions from Couroupita guianensis Aubl. leaves. J Ethnopharmacol. 12:407-413.

Pinheiro MMG, Fernandes SBO, Fingolo CE, Boylan FB, Fernandez PD (2013) Anti-inflammatory activity of ethanol extract and fractions from Couroupita guianensis Aublet leaves. J Ethnopharmacol. 146:324-330.

Quasem JR (1995) The allelopathic effect of three Amaranthus spp. (Pigweeds) on wheat (Triticum durum). Weed Res. 35:41-49.

Salam MA, Kato-Noguchi H (2009) Screening of allelopathic potential Bangladesh rice cultivars by donor-receiver bioassay. Asian J Plant Sci. 8:20-27.

Sathe SB, Sonawane AA, More SH, Jadhav AP, Kadam V (2013) Cannonball tree - a review. Indo American J Pharm Res. 3:6327-6335.

Swapnalatha S, Devi RV (2014) Antidiabetic activity of Couroupita guianensis -A review. IOSR J Pharm Biol Sci. 9:41-43.

Thi LH, Lin CH, Smeda RJ, Leigh ND, Wycoff WG, Fritschi FB (2014) Isolation and identification of an allelopathic phenyl ethylamine in rice. Phytochemistry. 108:109-121.

Weir TL, Park SW, Vivanco JM (2004) Biochemical and physiological mechanisms mediated by allelochemicals. Curr Opin Plant Biol. 7:472-479.

Yoshimura H, Sawa Y, Tamotsu S, Sakai A (2011) 1, 8cineole inhibits both proliferation and elongation of by-2 cultured tobacco cells. J Chem Ecol. 37:320-328. 